\title{
Transformativní charakter performance: Od symbolického jednání k liminalitě a politickému divadlu
}

\author{
Transformative Character of Performance: \\ From Symbolic Action to Liminality and Political Theatre
}

Tereza Došlová

\begin{abstract}
Abstrakt
Překládaná studie vychází z proměny vztahu mezi divákem a aktérem, která se udála v souvislosti s performativním obratem. V první části autorka mapuje myšlenkové kořeny konceptu liminality $\vee$ německé teatrologii s důrazem na práci německé teatroložky Eriky Fischer-Lichte, které liminalita slouží k popisu transformativního charakteru současných performance. Druhá část textu má podobu prípadové studie, v níž autorka analyzuje projekt souboru Rimini Protokoll s názvem Träumende Kollektive. Tastende Schafe /Staat 3/ [Snící kolektivy. Tápající ovce (Stát 3)], uvedeného v drážd'anském Schauspielhausu. Na vybraném interaktivním projektu studie ukazuje, jakým způsobem se diváci dostávají ze svých komfortních zón do hraničních stavů. Projekt souboru Rimini Protokoll je v textu zkoumán jakožto příklad současné postdramatické linie politického divadla, která má potenciál ovlivnit diváky ve smyslu přehodnocování jejich dosavadních postojů a názorů, a to právě díky liminálnímu zážitku. Ukazuje tedy, jakým způsobem může být politikum vtěleno do samotné participativní divadelní estetiky.
\end{abstract}

\section{Klíčová slova}

transformativní charakter, liminalita, performance, politické divadlo, interaktivní divadlo, postdramatické divadlo, Rimini Protokoll

\begin{abstract}
This article works with the transformation of the actor-spectator relationship which happened in theatre along with the performative turn. First, the author conducts a survey of the philosophical roots of the 'liminality' concept in the German theatrology, with special focus on the works of German theatrologist Erika Fischer-Lichte, who uses liminality in order to describe the transformative character of contemporary performances. The second part of the article presents a case study, in which the author, using the liminality perspective, analyses the project of the theatre group Rimini Protokoll named Träumende Kollektive. Tastende Schafe /Staat 3/ [Dreaming Collectives. Tapping Sheep (State 3)], staged in Schauspielhaus, Dresden. Using this selected interactive project, the article focuses on the way audience leave their well-known, comfort zone and enter a liminal state, characterised by a strength-
\end{abstract}


ened self-reflection. Rimini Protokoll's project is examined as an example of contemporary postdramatic tendency in political theatre, which has a potential to influence the audience and their reassessment of their standpoints and opinions through the liminal experience. The case study therefore describes the way politicum can be incorporated into the participatory theatre aesthetics.

\section{Key words}

transformative character, liminality, performance, political theatre, interactive theatre, postdramatic theatre, Rimini Protokoll

Pasivní participace je již od antiky převládajícím a obecně přijímaným modem divácké recepce. I když diváci na divadelním představení participují vždy psychicky, emocionálně nebo intelektuálně, od počátku 20. století se objevují režisérské osobnosti, které se ve své tvorbě soustředí na důležitost zapojení publika do výsledného tvaru. Vsevolod Mejerchold, Erwin Piscator, Bertolt Brecht, Antonin Artaud, Jerzy Grotowski nebo Augusto Boal pobízeli své diváky k prrímější participaci s cílem podnítit jejich kritické myšlení, způsobit psychický šok nebo navodit jakousi rituálně-mystickou atmosféru a tím transformovat mimodivadelní skutečnost. Západní divadlo prošlo v šedesátých etech tzv. performativním obratem, přičemž jedním z jeho zásadních aspektů byla právě redefinice vztahu mezi divákem a hercem. Divadelní tendence od té doby míŕí k rozvolnění pojmů „tvưrce“ a „recipient“; od diváků již není očekáváno „pouhé“ pozorování, interpretace a porozumění danému tvaru, ale naopak jsou vtahováni do uměleckého procesu. ${ }^{1}$ Německá teatroložka Erika Fischer-Lichte dokonce hovoří o tom, že se divadlo odvrací od snahy reprezentovat ucelený fikční svět, namísto toho vytváří spíše realitu, do níž diváka vtahuje a podněcuje ho prostřednictvím zvýšené interaktivity k jejímu prozkoumávání (FISCHER-LICHTE 2008: 18-22). Divadelní umělci se svými diváky počítají jako se spolutvưrci, bez nichž by projekty ve výsledku nemohly být vůbec realizovány. O emancipaci publika a individualizaci jejich zážitku skrze nejrůznější imerzivní a participativní strategie hovoří i německý teoretik a profesor aplikované divadelní vědy Hans-Thies Lehmann a považuje je za jedny z nejzákladnějších charakteristik postdramatického divadla (LEHMANN 2007: 310). ${ }^{2}$ Právě tímto termínem pojmenovává radikální proměnu divadla druhé poloviny 20. století, přičemž ji ukazuje na množství příkladů z praxe.

$1 \quad \mathrm{O}$ proměně vztahu $\mathrm{k}$ divákovi píše i teoretik a režisér Richard Schechner (např. ve své sbírce esejí Performancia: teorie, praktiky, rituály, která vyšla ve slovenském překladu). Konkrétně dokonce hovoří o tom, že divadlo ve 20. století začalo tematizovat diváctví.

2 Myšlenka zesílené participace v divadle, jež nese potenciál přímo ovlivnit diváky, nepř́isluší pouze postdramatickému divadlu. Setkáváme se s ní mnohem dříve například v konceptu divadla utlačovaných Augusta Boala. Boal využíval nejrůznější participativní techniky a strategie právě s onou vírou, že dokážou diváky podnítit $\mathrm{k}$ politické akci a zapř́ičinit jejich společenskou transformaci. Diváci se v jeho divadle nazývaném fórum stávají zodpovědnými za průběh i výsledek; v pozici herce si mnohem více kriticky uvědomují, co vidí a co dělají, čímž mají dospět k závěru, že i v reálném životě jsou strůjci svého osudu a že jejich snažením můžou podobných změn dosáhnout i mimo divadlo. 
Mezi nimi najdeme také Lehmannovy žáky z Institutu aplikované divadelní vědy v německém Giessenu Helgardu Haugovou, Stefana Kaegiho a Daniela Wetzela; vůdčí umělecké trio německého souboru Rimini Protokoll, které je považováno za původce specifické dokumentární formy divadla zapojující do výsledných tvarů tzv. experty všedního dne. Rimini Protokoll nepracuje s existujícími textovými předlohami či profesionálními herci; namísto nich se divák na jevišti střetává se skutečnými odborníky na určité téma, kteří disponují speciálními vědomostmi, jež zpravidla vycházejí z jejich vlastní životní zkušenosti. Způsob jejich tvorby však kromě zmíněných expertů vystihuje i soustředění se na zvýšenou interaktivitu s divákem, na jeho aktivizaci a maximální zapojení do výsledného tvaru.

Skupina je pro svou mnohdy až „kronikářskou“ práci s biografiemi, konkrétními vzpomínkami vyprávějících doplněnými fotografiemi, videozáznamy, nahrávkami aj., považována za poměrně novátorskou v oblasti dokumentární linie politického divadla. To v Německu navazuje na silnou tradici, formovanou především v šedesátých a sedmdesátých letech minulého století. Hlavním tématem divadla té doby, inspirovaného společensko-kritickými experimenty s dokumentárními materiály Erwina Piscatora, ${ }^{3}$ bylo především vyrovnávání se s německým podílem na válečných událostech, jako byl holokaust nebo svrhnutí atomové bomby na Hirošimu a na Nagasaki. ${ }^{4}$ Dokumentární tvorbu Rimini Protokoll lze naproti tomu v tematické rovině charakterizovat poněkud šiř̌ji. V centru jejich zájmu stojí člověk obklopený společenskými strukturami a jevy, jež produkuje současná globalizovaná společnost. Proto v jejich projektech najdeme jak explicitní tematizaci politiky (Deutschland 2, 2002; Valdštejn, 2005; Karel Marx: Kapitál, Pruni svazek, 2006; Adolf Hitler: Mein Kampf, Band 1E22, 2016), tak i náměty, jež

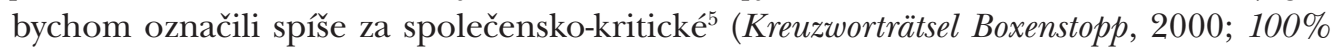
City, 2008; Vùng biên giơ'i-Místo na hranici, 2009; Qualitätskontrolle, 2013). Můžeme tedy tvorbu souboru Rimini Protokoll označit za politickou? A v čem vlastně ono politično v divadle spočívá?

3 Piscator zformoval program angažovaného divadla v knize Politické divadlo (1929). Jeho Proletářské divadlo, založené v roce 1920, apelovalo na dělnický lid a mělo v něm vzbuzovat odpor vưči vykořistovatelům, proto šlo o skutečně uvědomělou propagandu. Piscator navíc ve svém divadle využíval dokumentární materiály, technické postupy (projekce, film, kamera, světelná režie, reproduktory) a média, kterými chtěl zvýšit emoční vliv na diváka. V roce 1951 se po letech strávených v zahraničí vrátil do Západního Německa a od šedesátých let působil jako ředitel Freie Volksbühne, kde opět pěstoval ostře společensko-kritické divadlo.

4 Představitelé dokumentárního divadla šedesátých let jsou Peter Weiss, Rolf Hochhuth, Heiner Kipphart a nelze opomenout ani Piscatora, který se na hnutí německého divadla šedesátých let taktéž výrazně podílel.

5 Při odlišení témat politických a společensko-kritických vycházím z užšího vymezení tohoto př́ivlastku, které ve svém textu On Political Theatre uvádí americký teoretik Michael Kirby: „Politické je 1) zaujetí vládou a všemi orgány státní správy, státem a politikou v tom nejužším slova smyslu; 2) všechno, co má jasně definovanou vládní strukturu; 3) angažovanost v politice a zaujímání politického postoje, např. ve prospěch určité politické strany; 4) ztotožnění se s charakteristikami politických stran a politiků a jejich další použití k nejrůznějším účelům, např. k širření politické ideologie, nátlaku, aj.“ (KIRBY 1975: 129). Jestliže pak politickým nazýváme vše, co se týká politiky v nejužším slova smyslu, politiky per se; společenská jsou témata, která se týkají lidské společnosti v celé její šíri. 


\section{Politické divadlo v současné německé teatrologii}

V přemýšlení o divadle má termín politické divadlo poněkud nejasnou pozici. Přihlédneme-li ke zmíněnému dokumentárnímu divadlu šedesátých let nebo k dřívější „piscatorovsko-brechtovské“ linii proletářského, revolučního až agitačně propagandistického divadla, zjistíme, že je shodně vystihuje přímočaré vyrovnávání se s politickými a sociálními tématy formou inovativního estetického tvaru. ${ }^{6}$ Současné pojetí politického divadla však míří poněkud jiným směrem; není již založeno na jednoduché dualitě formy a obsahu, je tematicky nepřímé, abstraktnější čili postdramatické.

Z toho důvodu se s termínem politické divadlo vyrovnává i současná divadelní teorie. Lehmann konkrétně hovoří o tom, že divadlo dnes nemůže být politické tím, že bude explicitně reflektovat současná témata. Sama naše společnost, jejíž struktury a témata se proměnily s nástupem nových technologií a digitálních médií, je dle něj natolik nepřehledná a složitá, že aktuální situaci nelze na divadle zobrazit. ${ }^{7}$ Divadlo už není centrem polis, jako tomu bylo v antické kultuře, je spíše menšinovou záležitostí, a navíc je oproti jiným médiím velmi pomalé. Lehmann proto jasně zdůrazňuje, že divadlo, které explicitně tematizuje politiku, je dnes již neaktuální. ${ }^{8}$ Politično v divadle se tedy podle něj ukrývá především ve vnímání, v tom, že v divadle můžeme na předkládané politické obrazy bezprostředně reagovat (LEHMANN 2007: 309). V případě projektů, jež navíc uplatňují v úvodu popsané interaktivní postupy, je divákům dokonce znemožněno zaujmout lhostejný postoj. Oni sami se naopak stávají zodpovědnými za formulované poselství (LEHMANN 2007: 310). ${ }^{9}$ Fischer-Lichte jde v úvahách o politickém divadle ještě dál a vztahuje ho k tzv. nové politice estetična, jímž označuje moment, kdy divák reflektuje vlastní politický postoj. Politika estetična se dle ní vymezuje vůči zkreslené mediální realitě, vưči př́lišné medializaci politiky, jež započala v devadesátých letech a trvá dodnes. U postdramatické linie politického divadla, která je obecně založena na narušování zaběhlých stereotypů diváckého vnímání, tedy politično spočívá nikoliv pouze v explicitním zobrazování politických témat, ale je součástí divadelní estetiky (FISCHER-LICHTE 2011: 59).

$6 \quad$ O problematice totalitních režimů a represí, které můžou být předpokladem pro rozvíjení kreativity a subversivních praktik politického umění, a o pozdějším odklonu od ideologií, jež je podstatný pro posuny v chápání politického divadla ve druhé polovině 20. století, hovoří Adam Czirak, spolupracovník Eriky Fischer-Lichte v projektu Kulturen des Performativen, v rozhovoru vedeném Tomášem Kubartem s názvem „Umění má ,komunikativní rozměr mlčení““ (CZIRAK 2018).

$7 \quad$ Na problém zobrazitelnosti aktuální situace v divadle upozorňoval už Friedrich Dürrenmatt ve svých Problémech divadla (1965), kde za jediný možný divadelní žánr považoval tragikomedii.

8 Lehmann ve svých tezích však opomíjí například postdramatickou tvorbu dramatičky Elfriede Jelinek, která od roku 1995 píše hry explicitně se vyrovnávající s aktuálními společenskými problémy (tzv. zeitstücky). Její tvorba pro divadlo tak odporuje také tvrzením tvůrců a teoretiků nového realismu, jež postdramatickému divadlu vytýkají př́lišnnou abstraktnost a fakt, že se nezabývají konkrétními problémy společnosti. Tvorbou Elfriede Jelinek se zabývá např́ílad (AUGUSTOVÁ 2020; AUGUSTOVÁ et al. 2017).

9 Proto také Lehmann píše o divadelní estetice zodpovědnosti, kterou může uplatnit pouze divadlo tím, že vytvář́ obrazy, významy v konkrétním čase a prostoru. Toto vnímání nazývá Lehmann nejen estetickým, ale i eticko-politickým (LEHMANN 2007: 309). 
Cílem překládaného textu je prostřednictvím případové studie prozkoumat právě tuto postdramatickou linii politického divadla, která sice podobně jako brechtovsko-piscatorovská pracuje s estetickými inovacemi - v postdramatickém divadle jsou dokonce často a zhusta využívány postupy Brechtova epického divadla - avšak liší se radikální proměnou vztahu $\mathrm{k}$ divákovi, kterou $\mathrm{v}$ zásadě definuje především systematická snaha tvůrců o narušení zaběhlých diváckých stereotypů vnímání.

\section{Od liminality k politickému divadlu}

Nástrojem mého zkoumání je koncept liminality, který Erice Fischer-Lichte slouží k popisu transformativního charakteru současných performancí a jenž detailněji zpracovává především v publikacích Theatre, Sacrifice, Ritual: Exploring forms of Political Theatre (2005) a The Tranformative Power of Performance: A New Aesthetics (2008). Teatroložka berlínské Svobodné univerzity představuje jednu z nejvýraznějších osobnostní současného myšlení o performativitě jako projevu nebo aspektu teatrality, opírající se o onu změnu paradigmatu, od něhož se začíná klást důraz na prezéntnost umění, tj. setkání aktérů a diváků $v$ jedinečné chvíli tady a ted'. Ve svém textu se zaměřuji především na kontext a vývoj německé divadelní vědy, v níž můžeme pozorovat dvě linie zkoumání: první je teatrologické uvažování o jedinečnosti divadla jako uměleckého druhu (co dělá divadlo divadlem), druhá tendence pak směřuje $\mathrm{k}$ výzkumu teatrality, $\mathrm{k}$ antropologii a jiným přidruženým oborům. Fischer-Lichte svým uvažováním o performativitě přispívá do obou těchto linií. S pojmem performance pracuje jak v užším, divadelním slova smyslu, tak ve smyslu přesahujícím jeho rámec. V jejím pojetí kulturní performance zahrnuje vše od nejrůznějších druhů náboženských a sociálních obřadů, rituálů, svátků, po sportovní, kulturní, politické události aj. Pojem performance nejenže umožňuje zkoumat fenomény, jež nepatří do oblasti divadla, s použitím jasnější metodologie, ale pomáhá také „osvětlit divadelní projevy z hlediska sociologie a antropologie“ (MUSILOVÁ 2014: 15), což je pro interdisciplinární myšlení německé teatroložky definující.

\section{Divadelní interakce jako symbolické jednání}

Myšlenkové kořeny konceptu liminality sahají v německé teatrologii k období nástupu tzv. druhé divadelní reformy. $\mathrm{V}$ tom momentě se pro popsání novějš́ích divadelních tendencí začíná doposud prosazovaný mimetický princip (tj. divadelní nápodoba skutečnosti) jevit jako nedostačující. Navíc také znatelně zaostával za interdisciplinárními vlivy přijímanými světovou divadelní vědou. $Z$ těchto důvodů se postupně začínají prosazovat úvahy o kontaktním, přímo interaktivním charakteru divadla. Takto směřované úvahy pak dále poskytly prostor pro př́stupy kombinujíć inspirace ze sociologie, antropologie či věd o komunikaci.

Nejvlivnější pokus o překročení hranic „mimologie“ představil v sedmdesátých letech Arno Paul, taktéž teatrolog Svobodné univerzity. Zásadní otázkou pro něj bylo, 
co je konstitutivním momentem divadla, přičemž odmítá jak koncept nápodoby skutečnosti, tak samotnou inscenaci. Paul přichází s tvrzením, že se „divadlo konstituuje jako specifická symbolická interakce, jen když vznikne bezprostřední bilaterální vztah mezi aktéry a publikem, který se odvolává na demonstrativní produkci a recepci jednání-jako-by a pohybuje se v konvenci stanovené relevantní oblasti“ (ROUBAL 2018: 17). Pojem symbolické jednání Paul převzal ze sociologie tzv. chicagské školy, konkrétně z práce Georga Herberta Meada a chápe ho jako jakési základní, elementární jednání, díky němuž se jedinci či skupiny navzájem dorozumívají a ovlivňují v myšlení, cítění a dalším jednání. Paul za nejdůležitější rysy této symbolické interakce považuje skutečnost, že jsou její účastníci vždy zároveň „jednajícími i pojednávanými“ (ROUBAL 2018: 17). Mají tudíž možnost se vidět nejen z vlastní perspektivy, ale i z perspektivy druhých.

Důležitým aspektem i formativní vlastností symbolického jednání je, že se teprve skrze něj z „biologické bytosti stává společenský člověk s vlastní osobností“ (ROUBAL 2018: 18). Paul ve svých úvahách označuje divadlo za náročnou aktivitu pro oba účastníky interakce z toho důvodu, že herci neustále oscilují mezi svým já vyskytujícím se v roli a vlastní identitou, tj. mezi fiktivní a reálně-empirickou rovinou. A stejně podvojné je i divákovo vnímání mezi smyslově, intelektuálně uchopitelnou divadelní fikcí a zprostředkovanou empirickou skutečností. Paul tímto akcentuje zcela zásadní moment, kdy divák dostává od aktéra prostřednictvím jeho role nabídku k identifikaci, tj. může si zkusit být někým jiným a to tak, že uskuteční feedback (zpětnou reakci). Tato vzájemná komunikace má svůj výsostně společenský dopad, význam a potenciál transformovat naši žitou realitu. Paul ve svých úvahách ruší základní rámování divadla, zdůrazňuje jeho schopnost vstoupit do každodennosti, což mu umožňuje zabývat se sociologickými a politickými účinky představení na diváka. ${ }^{10}$

Paulův koncept, který ve své podstatě připomíná sociálně a psychologicky domyšlenou brechtovskou představu o divadle, byl v osmdesátých letech značně kritizován pro své opomíjení estetické stránky divadla, nicméně je nesporné, že zároveň významně vstoupil do uvažování o pojetí divadla v německé teatrologie. ${ }^{11}$ Jeho zájem o procesualitu a interaktivnost byl jakýmsi prvotním impulzem k mnohem radikálnějšímu př́ístupu k divadlu jako k procesuální, událostní a participativní záležitosti.

\footnotetext{
10 Arno Paul byl stoupencem alternativního, lidového politického divadla, zabýval se například prací italského herce, dramatika, novelisty a divadelního režiséra Daria Fo.

11 Klaus Lazarowicz ve své studii s názvem „Triadická koluze“ (2005) představuje sice protikladnou koncepci, ale vychází z obdobně procesuálních, interaktivních tezí se zdůrazněním ludičnosti. Proti snahám o „reformu“ teatrologie však přichází s názorem, že na tom, co se odehrává mezi divákem a hercem, participuje ještě postava dramatika, a to vždy bez výjimky, jinak se jedná o pouhou „scénickou gymnastiku“, čímž polemizuje s alternativní divadelní praxí. Zároveň hájí princip respektování divadelní rampy, snahy o její odstranění přisuzuje evolucionářům a revolucionářmm.
} 


\section{Estetika performativity}

Fischer-Lichte však ve své Estetice performativity z roku 2004 (i dřívějších studiích) sahá hlouběji k počátkům samotné německé divadelní vědy, když se otevřeně hlásí k odkazu jejího zakladatele Maxe Hermanna. Už ten totiž artikuloval autonomnost divadelního díla zdůrazněním fyzické spolupřítomnosti aktérů a diváků a s tím spojeným přechodem „od znakového charakteru těla k charakteru materiálnímu“ (FISCHER-LICHTE 2011: 47) v opozici k tvrzení, že je divadlo „pouhým“ konotačním znakem literatury a herec nositelem předem daných významů. Autorčin koncept performativity pojí s Hermannem také zájem o prezéntnost představení, tj. ono „spoluprožívání skutečných těl ve skutečném prostoru“ (FISCHER-LICHTE 2011: 48), jež ruší vztah subjekt-objekt a naopak směřuje k partnerství subjektů. Fischer-Lichte navazuje také na Hermannův pojem hry, značící přesah k antropologii. Divadlo je v jeho pojetí „hrou všech a pro všechny“ (ROUBAL 2009: 64), přičemž nejenom, že se představení děje mezi aktéry a diváky, ale je oběma skupinami také přímo utvářeno - z toho pak německá teatroložka odvozuje pojem autopoetické zpětnovazební smyčky.

Fischer-Lichte nahlíží problematiku performance skrze specifickou mediálnost, materiálnost, sémiotičnost a estetičnost. Částečně se tak odklání od svých sémiotických studií z osmdesátých a devadesátých let, když akcentuje „antropologickou, akční i kulturně heuristickou povahu divadla“ (ROUBAL 2009: 64). Fischer-Lichte se na základě performativního obratu dovolává vytvoření estetiky performativity, která je postavena na pojetí díla jako události, změně vztahu subjektu a objektu i „materiálního znakového statusu“ (ROUBAL 2009: 64).

Z výše řečeného vyplývá, že základním rysem performativity, a společně s ní tedy i všech čtyř specifičností představení, je její událostní charakter. Pro sémiotičnost představení, tedy pro vznikání významu, je charakteristickým momentem oscilace mezi řádem reprezentace a prezentace, přičemž každý z nich generuje své vlastní významy. Oba řády, tj. vnímání znaku postavy prostřednictvím fiktivního světa a koncentrace na fenomén v jeho autoreferenčnosti, se v představení různě prolínají, přechody mezi nimi jsou dynamické, nestabilní, což přenáší pozornost na samotnou recepci v její procesualitě (FISCHER-LICHTE 2009: 18). Mediální povahou performance je pak interakce všech účastníků, tedy fyzická spolupřítomnost aktérů a diváku. Zprostředkovaná, interpersonální povaha divadla umožňuje každému účastníkovi zakoušet sama sebe jako subjekt, ,jenž dokáže spolurozhodovat o jednání i chování jiných a jehož jednání a chování stejnou měrou vyplývá z působení ostatních; tedy jako subjektu, jenž na sebe bere odpovědnost za situaci, kterou sám nevytvořil, ale pouze se v ní ocitl, a nyní v ní musí nalézt sama sebe“ (FISCHER-LICHTE 2009: 14). Teprve tehdy se může vyjevit transformační povaha představení. Materiálnost představení je generována „tady a ted”“ a paradoxně tedy nezanechává „žádný fixovaný a tradovatelný materiální artefakt“ (FISCHER-LICHTE 2009: 15). Specifika performance nakonec vycházejí i z autopoiesis zpětnovazební smyčky, díky které dochází z hlediska tzv. estetičnosti k „emerzi, destabilizaci (ne-li rozrušení) dichotomií; stavům liminality a s nimi spojenými transformacemi, jimiž účastníci procházejí“ (FISCHER-LICHTE 2011: 235). V autopoiesis 
zpětnovazební smyčky nezáměrně vznikají významy, které vyvíjejí specifický tlak na recipienta a realizují se v rámci liminálních stavů.

\section{Teatralita}

Dříve, než se detailněji zaměřím na koncept liminality, je důležité se pozastavit nad pojmem teatralita, jež s teorií performancí neodmyslitelně souvisí. Kořeny teorie teatrality sahají ve východoberlínské teatrologii k myšlenkám Bertolta Brechta a jeho spolupracovníka Manfreda Wekwertha a k pojetí divadla jako kulturní komunikace (MUSILOVÁ 2014: 11). Iniciátorem toho pojmu v německé divadelní vědě je Joachim Fiebach, který teatralitu pojímá jako koncept „komunikativně performativního a symbolického jednáni“ (MUSILOVÁ 2014: 11). V devadesátých letech se pak teatralitou začala zabývat i Fischer-Lichte, když poukázala na jeho dva odlišné významy. Teatralitu či jinak divadelnost, můžeme za prvé chápat jako soubor specifik a kritérií, dle kterých lze definovat divadelní umění jako zvláštní a svébytnou formu. Druhý význam pojmu pak rozšiřuje jeho aplikaci na mimodivadelní události; jinými slovy nabízí možnost zkoumat prostřednictvím teatrality divadelní projevy mimo estetickou oblast umění. Jedná se o ty projevy, kterými se zabývají kulturní vědy, antropologie nebo sociologie. Fischer-Lichte přímo píše:

Druhá varianta definuje divadelnost mimo rámec a okruh divadla jako autonomního umění či sociální instituce. V tomto případě „teatralita“ se zde chápe jako „všeobecně závazný zákon umělecké proměny světa, jak jej vnímáme“, je definována jako „před-estetický instinkt“ člověka [...] (FISCHER-LICHTE 2005c: 132)

Fiebach i Fischer-Lichte rozšiřují projevy teatrality směrem k sociální a kulturní antropologii a oba ji chápou jako vlastnost. Německá teatroložka koncept teatrality vymezuje jako spolupůsobení aspektů performance, inscenace, tělesnosti a vnímání, jako možnou základní kategorii kulturní teorie (FISCHER-LICHTE 2005a: 6). Teatralita tedy vždy vyplývá z nějaké konkrétní kulturní performance; z rysů, bez nichž by daná událost vůbec neexistovala (např. dresy-kostýmy fotbalistů během zápasu, struktura určená dvěma poločasy, základní hrací dobou aj.) a pouze díky ní nabývá smyslu a významu.

Pro účely této práce je důležité zmínit především myšlenky ruského divadelníka Nikolaje Nikolajeviče Jevrejnova, který na začátku minulého století rozšiřil své bádání týkající se teatrality do oblasti mimoestetické. Zajímal se o šamanské, církevní rituály, veřejné výkony tělesných trestů, nahoty a studu, zkoumal zvířecí chování aj. (FISCHER-LICHTE 2005a: 5). V Jevrejnových úvahách nacházíme také onen transformativníní aspekt: podobně jako Paul nechápe divadlo jako umění, které pouze zrcadlí realitu, ale spíše jako „stupňování a intenzifikaci proměn života“ (CARLSON 2002: 246). ${ }^{12}$ Americký teatrolog Marvin Carlson shrnuje Jevrejnovo pojetí teatrality tak, že „může být uznána jako základní prvek trvající vitality a požitku z divadla a performance a na druhé 
straně jako pozitivní vskutku oslavný výraz lidského potenciálu“ (CARLSON 2002: 249). Teatralitu je pak dle něj možné pozorovat jak v každodenním životě, tak v hraničních projevech rituálů přechodu či v náboženských rituálech.

\section{Koncept liminality}

Iniciačním bodem uvažování o transformativním charakteru současných performancí je jednak odvrat od reprezentace uceleného fikčního světa, který inicioval vnímání divadla prizmatem jeho procesuálního a interaktivního charakteru, ale také ono rozšíření teatrologických výzkumů do mimodivadelních oblastí. Obrat k performanci neznamená jen přesun pozornosti od struktury díla k procesu jeho uskutečňování, ale také vzájemné interdisciplinární prolínání antropologie, sociologie a teatrologie (koneckonců výsledkem tohoto obohacování je i proniknutí samotného pojmu performance do humanitních, uměleckých věd). Na počátku těchto vlivů stojí antropologové a sociologové Victor Turner a Erving Goffmann. Turnerovy poznatky o rituálech přechodu, sociálním dramatu a liminalitě se staly podnětnými pro sociologické bádání o performanci. Inspiroval se jimi nejenom Turnerův spolupracovník Richard Schechner, ale prostřednictvím jeho také samotná Fischer-Lichte.

Liminalita, pocházející z latinského slova limen (práh), je kvalita nejednoznačnosti nebo dezorientace, která se vyskytuje ve středním stadiu průchodu přechodovým rituálem, kdy účastníci již nedisponují svým pre-rituálním statusem, ale zatím nebyl dokončen přechod do stavu nového. Během liminální fáze obřadu účastníci „stojí na prahu“ mezi předchozím způsobem strukturování své identity, času nebo komunity, a novým způsobem, který přijímají po absolvování rituálu.

Původcem konceptu liminality je francouzský folklorista a etnolog Arnold Van Gennep, který o ní poprvé pojednal v knize Les rites de passage (1909, česky Přechodové rituály), kde ji zkoumá v kontextu obřadů v malých společnostech. Van Gennep (2018) své úvahy začíná tím, že identifikuje různé kategorie rituálů, přičemž rozlišuje mezi těmi, které vyústí ve změnu stavu jednotlivce nebo sociální skupiny okamžitě na jedné straně a jejichž důležitost tkví v přechodu v průběhu času na straně druhé. Od Van Gennepa pochází také základní trojitá konstrukce hraničního zážitku. V první fázi (la séparation/separation phase) jsou zrušeny všechny dosavadní hranice, známé struktury a rutiny, jež definují naši každodenní žitou realitu, v poslední fázi přijetí (la réincorporation/integration phase) pak rituál nastavuje hranice nové, jež se zároveň liší od toho, co účastník doposud znal. Pomezní, či jinak liminální fáze (la mise en marge/threshold, transformative phase), nacházející se mezi nimi, je od běžného života a známých společenských struktur oddělena prostorově i časově; je to stav, v rámci něhož účastník „zažívá“ totální rozpuštění všech dosavadních hranic, přičemž nové zatím ještě nejsou ustanoveny (VAN GENNEP 2018: 21-22).

Turner tyto tři transformační fáze od Van Gennepa přebírá, pouze o nich ve své eseji „Betwix and Between: The Liminal Period“ in The Rites of Passage z roku 1967 místy hovoří jako o preliminální, liminální a postliminální fázi (TURNER 2004: 155). Příno- 
sem jeho úvah o liminalitě je hlavně to, že se postupně vzdálil od aplikace tohoto konceptu výhradně na přechodové rituály menších společností a poznatky pak vztáhl do širšího etnologického kontextu. Uvědomil si, že liminalita neslouží pouze k identifikaci důležitosti hraničního stavu, ale také k pochopení samotných lidských reakcí na tento zážitek - na způsob, jakým ovlivňuje osobnost, zda zapříčiní skutečnou déletrvající změnu myšlení, postojů, stanovisek čili jinak „jak se zpětně spojuje myšlenka se zážitkem“ (TURNER 2004: 155). Byl to také on, kdo liminální stav označil za nutně nejednoznačný, matoucí, dezorientační, jež má však zřetelný potenciál podnítit nové pohledy na žitou realitu. Turner zdůrazňuje nejen myšlenkové, ale i prostorové a časové vytržení z běžných způsobů společenského jednání a tvrdí, že právě tato hraniční zkušenost by měla být vnímána jako období zkoumání centrálních hodnot a axiomů kultury, v nichž jsou normální limity myšlení, sebepoznání a chování zrušeny. V takových situacích je samotná struktura společnosti dočasně zrušena či pozastavena.

Dle něj však musí být liminalita vždy pouze přechodným, byt’ značně intenzivním stavem, po němž se musí jedinec bezpodmínečně vrátit do svých sociálních struktur, nebo si může osvojit nové, a to třeba i s lidmi, kteří projdou stejným zážitkem - Turner pak tato společenství nazývá „normativními komunitami“ (TURNER 2004: 155). Myšlenka komunity je pro autora zásadní i během samotné liminální fáze - pokud ji zažívá najednou větší počet lidí, budují si automaticky vlastní společnou komunitu (TURNER 2004: 155) a pocit kamarádství k jejím členům na základě „společné synchronizace a úplného ponoření do jedné tekuté události“ (TURNER 2004: 155).

Turner na rituály nahlížel jako na sociální procesy, které lidem slouží k řešení krizových situací a mají tudíž především funkční hodnotu. Interakce, vznikající během rituálů, nazval dramatickými, protože dle něj mají většinou veřejný charakter. Každá taková interakce v sobě zahrnuje nepřeberné množství symbolů, jež udávají směr veřejného života. Po veřejné interakci dochází k ničení pout, která byla do té doby udržována psanými nebo nepsanými pravidly. V této souvislosti vzniká ve skupině krize a původní oddíl se důsledkem této interakce rozpadne na dvě odlišné skupiny. Následné nápravné jednání v podobě rituálních opatření podnítí obě skupiny bud' ke znovusjednocení, nebo naopak k úplnému rozkolu. Turner (2004: 156) si pokládal otázku, co se stane s lidmi, kteř́i jsou takto propojeni nebo rozděleni. Jak zážitek z rituálu (tj. kulturní performance) dokáže transformovat realitu po jejím skončení? Právě tuto formu procesů nazývá Turner „sociálním dramatem“. Jedná se o funkční model zlomu, krize, nápravy a výsledku. ${ }^{13}$

Turner tedy na rozdíl od Van Gennepa zdo̊razňuje onen transformační potenciál, který Fischer-Lichte považuje za nedílnou součást divadla. Tvrdí, že performance jsou ve své podstatě podobné rituálům. I v nich se diváci dostávají ze svých emociálně komfortních zón do jakéhosi „mezistavu“, tedy do fáze mezi dvěma stabilními stavy (stavem

13 Ve své pozdější práci začal Turner (např. knihy From Ritual to Theatre: The Human Seriousness of Play z roku 1982 nebo The Anthropology of Performance z roku 1986) zkoumat komplexní vztah mezi rituálem a divadlem, tj. momenty, kde se střetává rituální proces a umělecké nadšení. V osmdesátých letech také začíná spolupracovat se Schechnerem, s nímž detailněji zkoumá a rozvíjí myšlenky z oblasti performativity. Performance se tak postupně stala středem Turnerova myšlení, viděl v ní živoucí příklad rituálního jednání. 
před a po performance), kde navíc zažívají pocit zesílené sebereflexe. Filozofka Alice Koubová však ve své studii „Filosofické aspekty Estetiky performativity“ (2020) také upozorňuje, že Fischer-Lichte hovoří v souvislosti s performativitou o poněkud jiné liminalitě, než výše zmínění autoři rituálních teorií; respektive se jedná a koncept od nich odvozený:

Performance na rozdíl od přechodového rituálu nemění sociální status zúčastněných, jejich identitu, ani společenskou moc [...] - herní vystoupení z kontextu života, které performance nabízí, není rituální změnou, není přechodem jinam, je setrváním ve stejném, které můžeme významově posunout. (KOUBOVÁ 2020: 26) ${ }^{14}$

Kritika Koubové se ve své podstatě nese v podobném duchu jako pozdější přehodnocení termínu liminalita samotným Turnerem. K tomu u něj došlo přibližně v roce 1974 pod vlivem celkové proměny společnosti z kmenové, agrární na moderní a průmyslovou, společně s níž začíná oddělovat stavy liminální a liminoidní. V minulosti byly přechodové rituály zpravidla neodmyslitelnou, mnohdy povinnou, symbolickou až svatou součástí každodenních životů; naopak v současném světě je namísto kolektivních povinností kladen důraz na individuální prožitky. Svou roli v proměně společnosti sehrálo také striktní oddělení pracovních světů od volnočasových aktivit a pochopitelně také nástup nových technologií a médií. Právě ty vytvářejí prostor pro tzv. liminoidni zážitky, které v podstatě nesou stejné charakteristiky jako prožitky liminální, nicméně důležité je, že nejsou podmíněny změnou sociálního statutu účastníka, nejsou vázány na kolektivní pocit a jsou zpravidla těžko popsatelné. Jsou to hraniční, transformativní momenty v čase jedince, zcela odpoutané od společenských struktur (např. účast fanouška v davu při sportovním utkání nebo zážitky spojené s paraglidingem, parašutismem nebo závěsným létáním). Rozšíření termínu limioidni na divadelní performance pak můžeme sledovat u Richarda Schechnera, který v důsledku upozorňuje na problematičnost aplikace původního konceptu liminality na události současnosti. V složitě strukturovaném společenství, v němž nehrají rituály ústř̌ední význam a kolektivy nemusí sdílet vzájemnou platnost symbolických objektů, se rituály se stávají především inscenovanými událostmi, jejichž podobu určuje intence samotných tvůrců.

\section{Snící kolektivy. Tápající ovce}

Podívejme se nyní prizmatem tranformativního potenciálu performance na tvorbu Rimini Protokoll. V divadelních projektech jako 100\% City (2008), Best Before (2010) či Situation Rooms (2013) tvůrci opouštějí od původního modelu divadla pevných inscenací s předem vybranými experty všedního dne (i když někdy postupy kombinují) a činí experty přímo $\mathrm{z}$ diváků. Přidělením rolí účastníkům performance v rámci vytvářené

14 Alice Koubová (2020) shrnuje a částečně také reviduje své původní myšlenky formulované v knize Myslet z druhého mista (2019), v níž propojuje filozofické myšlení s divadelní tvorbou v tzv. performativní filozofii. 
fikční reality se nesnaží o pouhé „ukázání“ politických a sociálních procesů a struktur naší společnosti, ale nabízí je k vlastnímu a intenzivnějšímu prožití. Publiku je umožněno zkoumat vlastní reakce, stimuly a uvědomovat si svou pozici zkoumaného objektu, tedy určené role v tvorbě výsledného tvaru, i reflektujícího subjektu či jinak účastníka, jemuž je tvar adresován.

Projekt s názvem Snici kolektivy. Tápajici ovce (Stát 3) 3$)^{15}$ spadá do výše popsané interaktivní linie tvorby Rimini Protokoll. V analýze, která následuje v této části studie, vycházím z předpokladu, že politično podobně koncepčně řešených projektů Rimini Protokoll nespočívá jen v tematizaci současných politických problémů a otázek, ale je zakotveno v jejich samotné participativní divadelní estetice.

Režisér Wetzel projekt Snici kolektivy. Tápajici ovce vsazuje, prostřednictvím vlastní zkušenosti expertů všedního dne Kostise Kallivretakise a Vassilise Koukalaniho, do kontextu řecké finanční krize, která zapř́činila hrozbu Grexitu, tj. odchodu země z eurozóny, jehož se týkaly několikeré parlamentní volby. $\mathrm{V}$ roce 2015 jedny takové vyhrálo levicové hnutí SYRIZA, známé svou nechutí splácet státní dluhy, ale hlavně podporou Grexitu a odmítáním evropské měny (naopak prosazovali původní řeckou drachmu). Vyjednávání s druhou vítěznou stranou Nezávislí Řekové, doprovozené generálními stávkami po celém Řecku, trvalo neúspěšně několik měsíců, a tak premiér Alexis Tsipras vyhlásil referendum o záchranném programu 2015 (známé také jako referendum o přijetí návrhů mezinárodních věritelů na řešení řecké dluhové krize). Na tom by samo o sobě nebylo nic zvláštního, kdyby kritické ohlasy nevzbudila jak délka a složitá formulace otázky na hlasovacím lístku, ${ }^{16}$ tak i samotné pořadí odpovědí: jako první byla uvedena možnost „neschvaluji (ne)“ a až poté „schvaluji (ano)“. Koneckonců i samotné použití slov „schvaluji“ a „neschvaluji“ bylo považováno za matoucí. Ǩekové nakonec ve volbách řekli NE, čímž podpořili levicovou vládu a tím i Grexit. ${ }^{17}$

Snici koletivy. Tápajici ovce patří do tetralogie nazvané Staat $1-4,{ }^{18} \mathrm{v}$ níž se soubor soustavně věnuje otázce, jakým způsobem politicky nezainteresované osoby či různá média a sítě získávají vliv v post-demokracii. Každý z dílů reaguje na krizi demokracie, s níž se potýká současná společnost a která přirozeně podnítila větší participaci občanů v politickém rozhodování. Politické orgány jsou nyní, zdá se, spravedlivě voleny a měly by proto zastupovat společné blaho většiny občanů. Situace má však ještě druhou

15 Rimini Protokoll: Träumende Kollektive. Tastende Schafe (Staat 3), koncept, scénář, režie: Daniel Wetzel, spoluautorka: Ioanna Valsamidou, scénografie: Magda Plevraki, design softwarového systému a realizace: Dimitris Trakas, světlo a technická režie: Martin Schwemin, dramaturgie: Julia Weinreich, video animace: Grit Schuster, video Mathias Oster, statistická videa Caspar Schirdewahn, produkce Violetta Gyra a Paula Oevermann, Staatsschauspiel Dresden, prem. 23. 9. 2017.

16 Otázka zněla zhruba následovně: „Měl by být přijat návrh dohody předložený 25. června euroskupině Evropskou komisí, Evropskou centrální bankou a Mezinárodním měnovým fondem, sestávající ze dvou částí tvořících celý návrh?“

17 Ministerský předseda však výsledků referenda nedbal a v důsledku prohlubující se krize začal vyjednávat s představiteli Evropské měnové unie a Řecko nakonec získalo finanční pumpu z evropských peněz a je tudíž stále součástí EU.

18 Tetralogii tvoří tituly Top Secret International (Staat 1), Großbaustelle /Staat 2/ [Společnost ve výstavbě (Stát 2)] a Weltzustand Davos /Staat 4/ [Stav světa Davos (Stát 4)]. 
odvrácenou stranu v podobě stratégů, „píáristů“, soukromých poradních a právních týmů, kteří pomalu ale jistě přebírají otěže moci z rukou politiků, aby za použití stále sofistikovanějších reklamních kampaní a PR strategií globálně ovládli vrstevnatou a roztřrištěnou společnost. Všechny čtyři inscenace tetralogie tak spojuje otázka, kam až tato decentralizace politické moci povede.

Koncept Snicich kolektiviu. Tápajicich ovcí nabízí odpověd' svým tematickým i formálním zaměřením na zkoumání možností nových technologií, které se podílejí na politických rozhodnutích. Wetzel společně se scénografkou Magdou Plevraki vytvořili v drážd’anském Schauspielhausu, kde je projekt uváděn, doslova digitální realitu, která divákovi umožňuje vystoupit $\mathrm{z}$ reality a ponořit se do vymezeného prostoru reality performance. Projekt je zahájen upozorněním reprodukovaného hlasu softwaru představujícího Siri, digitální osobní asistentku v zařízeních společnosti Apple, že se jedná o testování, prováděné dne 10. ř́ijna 2047. Divákům jsou následně určeny role testovaných subjektů a je od nich tudíž vyžadována aktivní participace na utváření fikce jakési dystopické společnosti, v níž lidské rozhodování zcela ovládají technologie. K atmosféře digitálního prostoru přispívá pochopitelně také scénografie, kterou tvoří bílé krychle, rozestavěné na bílé podlaze tak, že vizuálně připomínají klávesnici počítače, a dvě obrovská promítací plátna umístěna po stranách.

Celé testování má pět částí. V první jsou diváci svými průvodci Kaliivretakisem a Koukalanim instruováni, aby přes iPhony, jež jsou všem přiděleny, odpovídali na pokládané otázky, týkající se nejrůznějších tematických okruhů. Každá z nich je přitom po vzoru řeckého referenda formulována nejasně a poměrně dlouze, takže vyměřený čas účastníkủm zdaleka nestačí. Odpovědi jsou následně vyhodnocovány zobecňujícími grafy, které se promítají na plátna, vždy doprovázené hudbou či ptačím cvrlikáním. $\mathrm{V}$ druhé testovací části jsou účastníci rozděleni do skupin podle barev z grafu - zelená se na iPhonech objeví těm, jež odpovídali dle většiny, modrá účastníkům, kteří „zaklikli“ menšinovou odpověd’. „Modří“ zůstávají stát na bílých krychlích a musí odpovídat na doplňující otázky ohledně jejich politických preferencí, kdežto „zelení můžou jen z kraje pozorovat. Třetí formální změna konceptu je nesena v duchu dalšího zmenšování testovacích skupin, to když se na obrazovkách iPhonů objeví číslo v procentech údaj, jenž označuje počet lidí, s nimiž mají účastníci nejvíc shodných odpovědí. Kallivretakis s Koukalanim všechny vyzývají, aby v prostoru našli takového člověka, který měl na svém telefonu stejné procentuální vyhodnocení. Dvojice pak opět na telefonech plní úlohy spojené s videem, na němž promlouvá německý pasák ovcí o chování svého stáda. Ve čtvrté části odpovídají participanti na otázky společně v několika skupinách, do nichž jsou přiděleny dle druhu ptáka, vyobrazeného opět na obrazovkách iPhonů (např. plameňák, papoušek či tukan). A konečně v poslední části jsou testovací subjekty odměněny poslechem orchestrální hudby, jež je složena ze všech jejich odpovědí.

Ve zkoumaném projektu Rimini Protokoll můžete pozorovat zřetelnou rituální strukturu. Vytržení z běžné reality a přechod do fikčního světa je symbolicky realizován hned na začátku Snicich kolektivui. Tápajicich ovcí. Divákům je umožněn vstup do digitálního prostoru až poté, co každý přede dveřmi odevzdal svou obuv. I když tedy publikum, z něhož se vzápětí stávají aktéři, původci veškerého dění v projektu, zůstává ve svém ci- 
vilním oděvu, přece jenom je propojeno do jedné interagující komunity. Fischer-Lichte hovoří také o transformativním potenciálu, který je obsažen v atmosféře obklopující performery a diváky. K elementům, jež tvoří onu atmosféru, patří zvuky, pachy, rytmy, světla a barvy (FISCHER-LICHTE 2005b: 64). Ty zároveň způsobují tělesné reakce publika a opět vytvářejí i dojem divadelní komunity, spojující jedince pocházející z odlišných sociálních a kulturních prostředí. Ve Snicích kolektivech. Tápajicich ovcích přispívá k atmosféře jak reprodukovaný hlas Siri, tak i orchestrální tóny, doprovázející každý vyhodnocující graf. Dojem digitálního prostoru podporují i světelné lasery, jež čas od času křižují hrací plochu a korespondují s barvami, které rozdělují účastníky testování do zmíněných skupin. Všechny tyto faktory ustanovují fikční realitu, do níž jsou diváci vtaženi a podněcují je k účasti na událostech, které se v ní mají odehrát.

Řekli jsme, že po první fázi následuje onen stav liminality, v němž jsou účastníci performance přeneseni mezi dvě sféry či dva světy. V této situaci jsou všechny doposud existující systémy a normy, ve které jedinec věří, zrušeny a diváci zatím ještě nejsou vtaženi do nově ustanovených sociálních struktur, konstruující uměle vytvořenou realitu. V liminální fázi se tedy publikum nemůže chovat podle přijatých standardů chování, což jedincům umožňuje zažít něco nového, dosud nepoznaného, možná znepokojujícího či šokujícího (FISCHER-LICHTE 2008: 22). Během tohoto procesu se ale zformované identity lidí, účastnících se fikčních událostí, nevytratí, ale zároveň již nemohou být vnímány jako stabilní, protože v dané chvíli procházejí změnami (FISCHER-LICHTE 2005b: 57).

Koncept Snicich kolektivů. Tápajicich ovcí simuluje celoplošný sběr dat, v rámci něhož jsou účastníci vedeni hlasem digitálního osobního asistenta, dostávají úkoly, odpovídají na otázky a musejí pracovat s internetovými aplikacemi, tedy s formátem moderního vzdělávání. Diváci tak mají možnost na vlastní kůži zakusit realitu, v níž se zásadně proměňují dosud známé formy občanské spoluúčasti na důležitých rozhodnutích. V rámci fikčního světa jsou prováděny výhradně prostřednictvím digitálních médií, jež jsou nám předkládána jako forma ulehčení a zefektivnění celého procesu, avšak bez upozornění, že můžou ovlivňovat nejenom zpo̊sob rozhodování, ale samotné formování našich názorů. Ve Snicich kolektivech. Tápajicich ovcich je v divácích tedy navozen dojem opravdové individuální volby, když musí každý odpovídat na otázky.

Fakt, že se jedná o strukturovanou a předem danou formu, se z vědomí participantů během performance nevytrácí. Snad i z toho důvodu mají tedy tendenci nedodržovat po celou dobu nastavená pravidla, ale naopak proti nim vystoupit rebelujícím způsobem. Na to koneckonců upozorňuje také sama Fischer-Lichte: jakmile diváci zažívají jakousi destrukci sociálních struktur, hodnot a standardů, můžou si sami vybrat, zda budou v rámci performance jednat esteticky, nebo eticky (FISCHER-LICHTE 2008: 22). Můžou přistoupit na to, že se performance bude odvíjet dle vlastních nastavených pravidel, nebo do ní můžou intervenovat, podnítit nečekanou změnu a předem danou strukturu tak narušit. Dojem individuální volby je ve zkoumaném projektu podrýván, například tím, že někteří z účastníků (hlavně ti, kteří neuměli příliš dobře německy) nechávali otázky bez odpovědi. Jejich iPhony však i přesto svítily bud’to zeleně, nebo modře. Oscilace diváckého vnímání mezi totálním přijetím struktur této fikční reality a pojímáním performance jakožto konceptu, produkuje pochybnosti, zda je testování 
skutečné nebo zmanipulované. V př́ípadě Snicich kolektivů. Tápajicich ovci však tyto pochybnosti můžeme považovat za jeden ze záměrů projektu. Tvůrci tím upozorňují na nebezpečí přehnané důvěry $\mathrm{k}$ technologiím, které máme tendenci mylně považovat za objektivní. Je však nutné si uvědomit, že za algoritmy, jež generují výsledky našich voleb, stojí vždy lidský element se subjektivními preferencemi. Wetzel tudíž s participanty projektu sehrává stejně falešnou hru, jako nejrůzněǰš́ internetoví trollové, manipulátoři a autoři tzv. hoaxů na sociálních sítích, nebo také velkoplošné průzkumy, přebírající osobní data zákazníků od různých firem či obchodníků a produkující vágní grafy ohledně různých životních preferencí. Z diváků se tedy stává jakýsi snící kolektiv (träumende kollektive); nemyslící němá masa, která se nachází ve stavu snové či klamné důvěry v technologie.

Liminalita vytváří posuny a změny ve způsobech našeho přemýšlení. Pochybnosti vyvstávající během Snicich kolektiviu. Tápajicich ovci lze považovat nejenom za záměr projektu, ale z výše zmíněného vyplývá, že jsou také právě také touto změnou, která se může následně přenést do naší žité reality mimo performance. Přehodnocování často slepé důvěry v digitální technologie, jež jsou čím dál více uplatňovány v nejrůznějších oblastech našeho života, tedy diváci v poslední fázi integrují do svého myšlení ve skutečném světě. Je to jakési nové pochopení moderní společnosti, $\mathrm{k}$ němuž v projektu publikum dochází právě tím, že je mu dána moc, autorita a zodpovědnost za jeho průběh.

\section{Závěr}

Pokud přistoupíme na tezi o transformativní síle performance a její podobnosti s přechodovými rituály, lze skrze nabízený koncept liminality nahlížet na celou jednu linii současných participativních postdramatických projektů. Přímé podílení se diváků na výsledné konstrukci fikčního světa v interaktivních, imerzivních performancích, je bezpochyby obohacující i pro jejich mimodivadelní realitu. V liminální fázi performance, během které přestávají platit dosavadní sociální normy a pravidla naší žité reality, je divákům poskytnuta možnost uvažovat nad hierarchiemi, vztahy a strukturami, a to nejen vstupem do fikčního světa, ale především možností průběžně se podílet na jeho vytváření. Jakmile se z publika stávají aktivní subjekty, je jim dána také moc, autorita a zodpovědnost za výsledný tvar i výpověd', a díky participaci vedoucí k liminálnímu stavu se můžou diváci v poslední fázi znovu integrovat do reality s novou zkušeností získanou během performance.

Na základě předpokladu transformativního charakteru performance můžeme také tvrdit, že zkoumaný projekt souboru Rimini Protokoll využivá imerzivní strategie se snahou o zprostř̌edkování zcela nové divácké zkušenosti, podněcuje publikum k jejímu dalšímu reflektování, diskutování, ke zpracovávání zážitku a touto cestou ke zvědomění nově nabytých postojů a zkušeností. Prvním stadiem přijetí takové zkušenosti do reality může být diskutování o zážitcích v divadelních barech a kavárnách, právě zde je totiž diváci zpracovávají, pojmenovávají a postupně integrují do svého světa. Rimini Protokoll tak ve svých interaktivních projektech vlastně realizuje požadavky současné německé 
divadelní teorie na podobu politického divadla, dle nichž politikum nespočívá pouze v tématu, ale je zakotveno v samotné estetice, způsobující proměnu diváckého vnímání během, ale hlavně po skončení divadelní události.

Vzhledem k tomu, že projekt Snici kolektivy. Tápajici ovce vypovídá o tématech současné „nerituální“ společnosti a zprostředkovává divákům zážitky z oblasti kognitivních procesů, které nejsou vázány na změnu sociálního statusu (naopak jsou výsostně individuální), nabízí se další zkoumání této performance, a to prostřednictvím Schechnerova pojmu liminoidni. K popsání specifického hraničního zážitku by bylo zapotřebí důkladnější analýzy publika, např́klad kulturního a socio-ekonomického backgroundu diváků, z čehož by bylo jasnější, jak rozumějí jednotlivým prvkům představení. Neprobádaná v tomto smyslu zůstává také samotná intence tvưrců události a otázky s tím související: do jaké míry je divákům skutečně dána moc a zodpovědnost za průběh představení? Nebo, a to je možná důležitější, zda tento efekt diváci během performance skutečně pocitují? Takové oblasti výzkumu jsou však v závěru zmíněny nad rámec předkládané studie, která je vzhledem k rozsahu a svému tematickému zaměření není schopna adekvátně postihnout. Nicméně však slouží k dalšímu promýšlení nejen zkoumané události, ale především pak samotného metodologického rámce a jeho aplikace na současné divadelní performance.

\section{Poděkování}

Na tomto místě bych chtěla poděkovat své školitelce doc. PhDr. Zuzaně Augustové, Ph.D. a pedagožce doc. Mgr. Martině Musilové, Ph.D. za odborné rady a konzultace.

\section{Bibliografie}

AUGUSTOVÁ, Zuzana, Jan JIŘÍK a Daniela JOBERTOVÁ (edd.). 2017. Horizonty evropského dramatu: současný divadelni text mezi dramatickými a postdramatickými tendencemi [Horizons of the European Drama: Contemporary Theatre Text Between Dramatic and Postdramatic Tendencies]. Praha: NAMU, 2017.

AUGUSTOVÁ, Zuzana. 2020. Experiment jako kritika nacismu. Poválečná rakouská experimentálni dramatická tvorba [Experiment as a Critique of Nazism. Postwar Austrian Experimental Drama]. Praha: Academia, NAMU, 2020.

CARLSON, Marvin. 2002. The Resistance to Theatricality. SubStance 31 (2002): 2/3: 238-250.

CZIRAK, Adam. 2018. Umění má „komunikativní rozměr mlčení“. Rozhovor s Adamem Czirakem. Rozhovor Tomáše Kubarta [Art has a 'Communicative Dimension of Silence'. An Interview with Adam Czirak. Interview by Tomáš Kubart]. Theatralia 21 (2018): 1: 181-185.

DÜRRENMATT, Friedrich. 1965. Problémy divadla [Theatre Problems]. Bratislava: SVKL - Slovenské vydavatel'stvo krásnej literatúry, 1965.

FISCHER-LICHTE, Erika. 2005a. „Ach, takové staré otázky...“ a jak s nimi zachází divadelní teorie dnes ['Those Old Questions...' And How Theatre Theory Treats Them Today]. Divadeln revue 16 (2005): 3-11. 
FISCHER-LICHTE, Erika. 2005b. Theatre, Sacrifice, Ritual: Exploring Forms of Political Theatre. London: Routledge. 2005.

FISCHER-LICHTE, Erika. 2005c. Divadelnost/teatralita a inscenace [Theatricality and Performance]. In Jan Roubal (ed.). Souřadnice a kontexty divadla: antologie současné německé divadelní teorie [Coordinates and Contexts of Theatre: An Anthology of Contemporary German Theatre Theory]. Praha: Divadelní ústav, 2005: 129-134.

FISCHER-LICHTE, Erika. 2008. Transformative Power of Performance: A New Aesthetics. London/ New York: Routledge, 2008.

FISCHER-LICHTE, Erika. 2009. Čím je představení v kultuře performancí? Pokus o definici [What is Theatre Performance in the Culture of Performances]. Divadelni revue 20 (2009): 3: $13-21$.

FISCHER-LICHTE, Erika. 2011. Estetika performativity [The Transformative Power of Performance]. Mníšek pod Brdy: Na Konári, 2011.

KIRBY, Michael. 1975. On Political Theatre. The Drama Review - Political Theatre 19 (1975): 2: 129-135.

KOUBOVÁ, Alice. 2019. Myslet z druhého mista: $k$ otázce performativni filosofie [To Think from the Second Place: To the Question of Performative Philosophy]. Praha: NAMU, 2019.

KOUBOVÁ, Alice. 2020. Filosofické aspekty Estetiky performativity [Philosophical Aspects of The Transformative Power of Performance]. Theatralia 23 (2020): 2: 13-29.

LAZAROWICZ, Klaus. 2005. Triadická koluze (O vztazích mezi autorem, hercem a divákem v divadle) [Triadic Collusion (On Relationships Between Author, Actor and Spectator in Theatre)]. In Jan Roubal (ed.). Souřadnice a kontexty divadla: antologie současné německé divadelni teorie [Coordinates and Contexts of Theatre: An Anthology of Contemporary German Theatre Theory]. Praha: Divadelní ustav, 2005: 23-30.

LEHMANN, Hans-Thies. 2007. Postdramatické divadlo [Postdramatic Theatre]. Bratislava: Divadelný ústav, 2007.

MUSILOVÁ, Martina. 2014. Teatralita veřejných událostí - uvedení do problematiky [Theatricality of Public Events - An Introduction]. Theatralia 17 (2014): 1: 9-24.

ROUBAL, Jan. 2009. Představení jako kaosmos. K jeho chápání v performativní estetice Eriky Fischer-Lichte a trochu i jinde [Performance as Kaosmos. Its Understanding in the Performative Aesthetics of Erika Fischer-Lichte and Also a Bit Elsewhere]. In Jan Hančil (ed.). Umění dialogu/The Art of Dialogue: Sborník z mezinárodního kolokvia. Praha: DAMU, 2009: 62-86.

ROUBAL, Jan. 2018. O podstatě divadla a teatrality (Pár nesoustavných poznámek k jejich koncepcím v současné německé divadelní teorii) [On the Essence of Theatre and Theatricality (A Couple of Unsystematic Notes About Its Concepts in Contemporary German Theatre Theory)]. In Jan Roubal. Hledáni souřadnic a kontextů divadla: př́spěvky $k$ současné německé divadelni teorii, k jejím otázkám, možným výzvám a inspiracím [Looking for Coordinates and Contexts of Theatre: Contributions to Contemporary German Theatre Theory, Its Questions, Possible Challenges and Inspirations]. Brno: Janáčkova akademie múzických umění, 2018: 15-40.

SCHECHNER, Richard. 2009. Performancia: teórie, praktiky, rituály [Performance: Theory, Practice, Rituals]. Bratislava: Divadelný ústav, 2009.

TURNER, Victor. 2004. Průběh rituálu [The Ritual Process]. Překl. Lucie Kučerová. Brno: Computer Press, 2004.

VAN GENNEP, Arnold. 2018. Přechodové rituály: Systematické studium rituálů [The Rites of Passage]. Praha: Portál, 2018. 


\title{
MgA. Tereza Došlová
}

Akademie múzických umění v Praze

Katedra teorie a kritiky, Divadelní fakulta

Karlova 26, 11665 Praha 1, Česká republika

tereza.doslova@damu.cz

\begin{abstract}
Tereza Došlová je doktorandkou na katedře teorie a kritiky Divadelní fakulty Akademie múzických umění v Praze, kde rovněž vyučuje. Odborně se zaměřuje na současné podoby politického divadla $v$ českém a německojazyčném prostředí, jeho tradice a teoretický diskurz. Věnuje se divadelní kritice, dramaturgii, produkční a PR činnosti. Bakalářský titul získala na Masarykově univerzitě $v$ Brně (obor Teorie a dějiny divadla a Teorie a dějiny filmu a audiovizuální kultury), v roce 2017 pak dokončila magisterské studium oboru teorie a kritika na pražské DAMU. $\checkmark$ roce 2019 se jako projektová manažerka podílela na organizaci mezinárodního sympozia Bertolt Brecht: Protiklady jako metoda, které se konalo pod záštitou Stanislavsky Research Centre Univerzity v Leedsu a platformou The S Word. Je členkou studentského evaluačního panelu instituce EQ-Arts (Enhancing Quality in the Arts), která organizuje hodnocení uměleckých studijních programů na evropských vysokých školách. Od roku 2021 působí jako externí redaktorka odborného recenzovaného časopisu Arte Acta.
\end{abstract}

Tereza Došlová is a doctoral student at the Department of Theory and Criticism, Academy of Arts Prague, where she also works as a lecturer. Her research interests include contemporary forms of political theatre in the Czech and German cultural space, its traditions and theoretical discourse. She also engages in theatre criticism, dramaturgy, theatre management, and PR. She gained her BA degree at Masaryk University (in the field of theatre studies and film studies). In 2017, she received her MA at the Department of Theory and Criticism, Academy of Arts, Prague. In 2019, she co-organised the international symposium Bertolt Brecht: Contradictions as a Method in collaboration with the Stanislavsky Research Centre, University of Leeds, and The S Word. She is a member of the student EQ-Arts (Enhancing Quality in the Arts) panel, which organises the evaluation of artistic study programmes at the European universities. Since 2021, she has been an editor of Arte Acta journal. 